\title{
Language choice among rural Mari families and their motives
}

Language choice is a core value of language policy that consists of three elements: management, or direct efforts to manipulate a language situation: practice, a sum of sound, word and grammatical choices that an individual speaker makes; and ideology, a set of beliefs about appropriate language practice (Spolsky 2004). Motives are related to the last component. As stated by researchers, language usage within a family can be determined by even one of these factors.

This article presents the results of an analysis of quantitative and qualitative data collected during my fieldwork in Mari El (Russia). Comparative analysis of the survey data confirmed the process of weakening of intergenerational language transmission among rural Maris and the fact that the linguistic behavior of family members varies by generation. Usage of Russian or Mari within a family is mainly the result of different values attached to each language and their social roles among certain sectors of society.

1. Introduction

2. Background information about the Maris

3. Method

3.1. Research instrument

3.2. Sample and participants

4. Linguistic image of rural Mari families

5. Factors affecting the languages used within Mari families

6. Code-switching within families

7. Conclusions

References

Appendix: Questionnaire

\section{Introduction}

Language choice is the core value of any language policy (Fishman et al. 1971), from the highest supra-national level to the level of the individual, i.e. when a person starts thinking about whether to speak one or another language. Of the overall set of domains, it is the family that first follows 
a language policy and thus determines the very linguistic repertoire of a person. Over the course of one's lifetime, the languages of communication can change several times.

According to Spolsky (2004), any language policy includes three components: language practice, which is "the habitual pattern of selecting among the varieties that make up its linguistic repertoire" (p. 5); language management, defined as "any specific efforts to modify or influence that practice ..." (p. 5); and language ideology, which implies certain beliefs about language and language use. Motives are a small but significant part of the last component, i.e. language beliefs. However, a combination of these elements is not an obligatory condition for language choice. As stated by Spolsky (2004), in some cases, the language used by a family might also be the result of an absence of language management; or, ideology might be a sufficient factor in influencing people's linguistic behavior, an aspect that was investigated for this paper. One often reads that the Mari language, culture and identity are best preserved in the countryside (Ivanov 2004; Sanukov 2011; Soloviev 2012). It is certainly the case that lifestyle of Maris, and, thus, their culture, are still strongly attached to rural areas (Soloviev 2012). This argument applies to all Finno-Ugric peoples (Sanukov 2011), as well as other minorities, in Russia. However, according to Lallukka (1990), the process of ethnic erosion is evident in rural settings. First of all, it manifests itself as a narrowing of the sphere of language use and a decrease in the number of native speakers. In the domain of the family, erosion is revealed through an increase in code-switching, i.e. "when speakers switch backwards and forwards between distinct codes in their repertoire" (Bell 2014: 113), or a complete shift to Russian. Moreover, general trend of rural exodus in Russia (Bychenko \& Shabanov 2012; Numurkhametova 2016) has accelerated ethnic erosion through assimilation (Lallukka 1990, 1997; Bychenko \& Shabanov 2014)

The goal for this paper was to study the motives behind language choices among rural Mari families. For this purpose, a social and psychological approach was taken, with the intention to investigate the social background of the participants. All conclusions were based on the analysis of empirical data collected by the author during fieldwork excursions in Mari El (2013, 2014, 2016).

The first part of the article provides background information about the Maris and the sociolinguistic situation in Mari El with a short history of the Russian context. In the second part, a brief description of the 


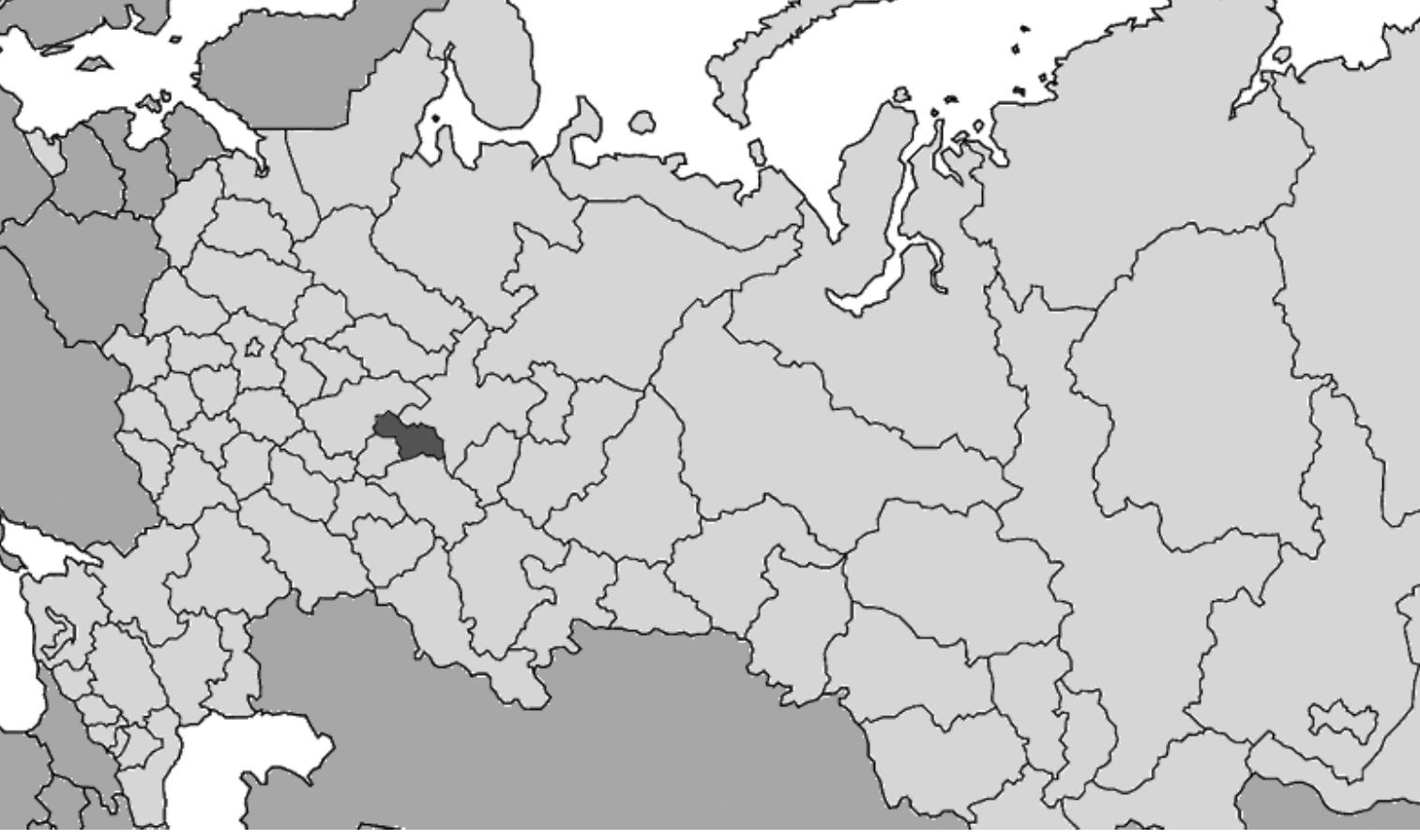

Figure 1: Map of the Mari El region within Russia

participants' social background (from the surveys and interviews) and families in general, grouped according to the language of communication, is presented. The third part gives an account of the use of either language by rural Maris in their communication with family members. All of the conclusions are intended to provide a clear explanation of why some modern Maris are more inclined to speak in Russian among their family than the Mari language, and why this is one of the primary reasons for ethnic erosion among Maris

\section{Background information about the Maris}

The Maris are one of the Finno-Ugric peoples settling in the Volga region of the Russian Federation. According to the 2010 Census data (Natsionalnyi sostav 2012), the total number of Maris in Russia is approximately 550,000. The official territory of the Maris is the Mari El Republic (Figure 1), which has a population of 680,500 , comprising $42 \%$ ethnic Mari, $45 \%$ Russian and $13 \%$ other ethnic groups.

The official state languages of Mari El are Mari ${ }^{1}$ and Russian. Despite its official status, the Mari language has a limited usage in the Republic: it is neither a language of instruction (though it is taught as a separate subject 
in $98 \%$ of schools), nor a language of business communication. Sixteen periodicals and approximately 30-45 books (a total of more than 45,000 copies) are published annually in the Mari language (Chuksin 2009; Vasiutina 2009). The Mari language is actively used on webpages (MariUver at http://mariuver.wordpress.com/; Respublika Mariy El, at http:// mari-el.name/) and social networks such as Vkontakte, Facebook, and Odnoklassniki (e.g. in the communities Чьллаже марий-влак ушныза!, Марий улам - марла илем! at http://vkontakte.ru and Тый марий улат мo? at http://odnoklassniki.ru). There is a Mari TV channel and a radio broadcaster, but both have limited broadcasting time (approximately 6.2 hours per week for TV news and programs in Mari) ${ }^{2}$.

The official history of the Maris in Russia begins in the 16th century, when the territory of the Mari was annexed from the Kazan Khanate by the Russian state ${ }^{3}$ (Sanukov 2011; Bakhtin 2012). Until the second half of the 19th century, the Maris lived in relative cultural isolation from the Russian majority (Sanukov 2011), but the implementation of governmental policies towards ethnic minorities in tsarist Russia (forced Christianization, the beginning of Russification) and Russification during the Soviet era (starting point is the end of the 1930s) resulted in closer contact between the two peoples. In 1990, the local Supreme Soviet established the former Mari ASSR (as it was officially titled from 1936 to 1990) as a republic with its own right to self-determination. This was also a time of high ethnic activism of the Maris, which had some influence on local politics (Sanukov 2010, 2012). However, in recent years, political activity among the Mari has declined significantly, mainly due to the different political stance of the local regional authorities, which has manifested in a reluctance to support the Mari ethnic movement (Shamiev 2010; Knorre \& Konstantinova 2013).

Despite official sources from Mari El regularly producing reports about successful language policies in the republic (Sbornik 2005; Shvetsova 2008, 2012), the real situation regarding the Mari language is rather complicated, as can be seen in the statistics (Natsionalnyi sostav 2012). According to census data, $80.8 \%$ of people self-identifying as ethnic Mari considered it their native language in 1989; by 2010, this figure had decreased to $76.0 \%{ }^{4}$.

As stated by researchers (Hint 1995; Ivanov 2004; Sanukov 2011), this linguistic situation is the result of Soviet language planning, which was directed towards linguistic and ethnic assimilation of minorities within Russia. Russian policies manifested in the ethnic erosion of Finno-Ugric minorities, which slowed with the fall of the Soviet Union in the last decade of the 
twentieth century (Lallukka 1995), but increased again at the very beginning of the third millennium. In the case of Maris, the most evident indicator of this erosion is a gradual replacement of Mari by the Russian language in all domains.

\section{Method}

\section{I Research tools}

In order to obtain information about the language practices of members of Mari families, a Revised questionnaire elaborated in the ELDIA project (from 2010 to 2013) was utilized. The questionnaire included 63 questions about the role of language in people's lives. However, within the framework of this paper, only data about language use in the family domain were analyzed. All responses were evaluated on a 3-point Likert scale.

A simplified and adjusted 32-item version of the Subjective vitality questionnaire by Bourhis et al. (1981) was used for collecting data about the language practices of Mari children in Mari El. The questionnaire was divided into four conceptual groups areas, one of which contained 10 questions about language use in various social situations. All responses were given using a 7-point Likert scale, which was later recoded into a 3-point scale to harmonize the data. The data from both surveys was processed using version 14.0 of the statistical package SPSS.

In order to obtain more detailed information about language choice within Mari families, eight open-ended interviews were conducted in March 2016 in Mari El. Of the eight interviews, two were telephone interviews and the rest were conducted face-to-face. They contained questions corresponding to one part of the Revised questionnaire about language use by family members (see Appendix). The total number of questions was 10. The families were divided into three linguistic groups (Group 1, Group 2, and Group 3). Group 1 contained families who communicated with each other using the Mari language, Group 2 contained families who communicated using both languages and Group 3 contained families who communicated in Russian. 


\title{
3.2. Sample and participants
}

The sample consisted of two age groups: adolescents (aged 13-17 years old) and adults (18-70). The data was collected by the author in Mari El during 2013 and 2016. Stratified (for the adolescents) and snowball (for the adults) sampling methods were used, the former to classify Mari adolescents by place of residence (city or rural) and the latter to classify Mari adults according to four social characteristics: age, gender, place of residence (city or rural), and education (basic, secondary, and higher). The revised questionnaire was completed by 104 Mari adults and the subjective vitality questionnaire by 376 adolescents. In accordance with the aim of the investigation, the samples of Mari adult and child groups were reduced to 61 and 222.

The interviewee sample included eight women, with the aim that they would represent their respective families. All of the participants were from rural areas except for one, who lived in a city. However, as the subject matter of the interview with the woman living in a city was language choice among her parental family, who lived in a rural area, the location of the interview was irrelevant. In order to ascertain the motives for selecting one language or the other, a short description of all the families is provided in the next section. For the sake of anonymity, the names of the participants have been changed.

Only women (predominantly married women) participated in the interviews. Husbands were not able to participate due to the inconvenient time of the interviews (during working time). Prior to that, a one-way between-group analysis of variance (ANOVA) had shown no statistically significant difference in the linguistic preference of participants within a Mari family by gender, so I allow myself to suppose that even interviewing only Mari women can provide more or less objective information about the linguistic situation among Mari families. All the information given regarding occupation and age was applied at the time of the interview. The families have been divided into groups as follows:

\section{Group I (Mari speakers)}

\author{
Family I \\ Maria (37) and Aleksey (42) live in Kugener village5 (Sovetskiy dis- \\ trict, Mari El). Maria is an assistant in a local shop and Aleksey a
}


worker in the local township plant. Both were born and grew up in the families with Mari as the language of communication. They have two children, a boy (Maxim, 13) and a girl (Nadezhda, 11).

\section{Family 2}

Anastasia (36) and Vitaliy (36) live in Kugener village. Anastasia is an assistant in the township shop and Vitaliy a worker in the local sawmill. Both were born and raised in Mari families, however, until Anastasia's marriage, she had communicated predominantly in Russian, whereas her spouse spoke in Mari. Anastasia and Vitaliy have three sons, Aleksey (14), Mikhail (12), and Vladimir (3).

\section{Family 3}

Anna (26) and Pavel (24) live in Kundyshumbal village ${ }^{6}$ (Sovetskiy district, Mari El). Anna is a nurse in the neighboring township hospital and Pavel a seasonal (from May to August) construction worker in Moscow. Both were born and raised in Mari families. Since early childhood, the language of communication in both families has been Mari. They have one son, Aleksander (3).

\section{Family 4}

Nataliya (25) and Vadim (32) live in Toshto Kreshyn village? (Orshanka district, Mari El). The Mari population forms a majority of the community, but due to the close proximity to a city (YoshkarOla), the proportion of Russian and Russian-speaking settlers in the village has been gradually increasing. Nataliya works as a cleaner in the city hospital and Vadim as a driver for a logistics company. They have two daughters, Kristina (3) and Ekaterina (6).

\section{Group 2 (speakers who actively practice code-switching)}

\section{Family 5}

Liudmila (34) and Mikhail (35) live in Ronga village ${ }^{8}$ (Sovetskiy district, Mari El). Liudmila is a logistics manager at the local hospital and Mikhail a seasonal (from May to August) construction worker in Moscow. They have three sons, Anton (15), Vladimir (9) and Nikolay (6). Since early childhood, Liudmila and Mikhail exclusively spoke Mari with their immediate family members. However, they 
frequently switch codes when communicating with each other and their children. Their children also speak both languages with one another. According to Liudmila, she makes a point of communicating with her children in Mari whenever possible.

\section{Family 6}

Larisa (34) and Vladislav (28) live in Solnechnyi township9 (Sovetskiy district, Mari El). Ethnically, the township is mixed, though the Mari population is dominant (Poselok 2014). Larisa is an assistant in the township shop and Vladislav a coal heaver at the local boiler station. Larisa was born and raised in a family who exclusively spoke Mari. In Vladislav's family, his parents sometimes switched to Russian when communicating with their children. The language of communication within Larisa and Vladislav's family is predominantly Russian, though Larisa has also attempted to teach Mari to their daughter Irina (3).

\section{Group 3 (Russian speakers)}

\section{Family 7}

Valentina (37) and Sergey (42) live in the village of Diemino ${ }^{10}(\mathrm{Ku}-$ zhener district, Mari El). The village is considered Russian (Derevnya 2014a), however, over the last 20 years the majority of the Russian population has moved to urban or near urban areas. Valentina is a laundress at the local kindergarten and Sergey a driver for a cooperative farm. The language of communication of their immediate families varies: in Valentina's it is Russian; in Sergey's it is a mixture of Russian and Mari. Valentina and Sergey have two children, a daughter, Elena (9), and a son, Konstantin (13). All have a good command of Mari, but use it only for communicating outside of the family

\section{Family $8^{\prime \prime}$}

Svetlana (57) and Igor (62) live in Shura village ${ }^{12}$ (Novyi Toryal district, Mari El), where the Russian population dominates (Derevnya 2014b). They have five children: two daughters, Anna (39) and Olga (27), and three sons, Yuriy (37), Leonid (34), and Denis (25). The language of communication between Svetlana and Igor is Mari, but they have spoken with their children in Russian since their early childhood. The language of communication between the children is Russian, though all can speak Mari fluently. 


\section{Linguistic image of rural Mari families}

Currently, the relevance of rural areas being a locus for the maintenance of the Mari language has not yet been determined, and it is subject to both objective (e.g. the language policy of the country and region; the poor economic situation of the state; a lack of natural recourses) and subjective (the indifference of some people to ethnic issues) factors. To address this, we created a linguistic image of a typical Mari family based on a statistical analysis of language choice among two age groups (adults and children), with various family members (between spouses, parents and children, and siblings), which allowed to compare a language choice from two perspectives: children and adults.

\begin{tabular}{|c|c|c|c|}
\hline & Parent & & \\
\hline Family member & Mari & Mari and Russian & Russian \\
\hline Parent & 51.0 & 17.6 & 31.4 \\
\hline Child & 43.6 & 38.2 & 18.2 \\
\hline
\end{tabular}

Table 1: Language use of Mari adults $(\mathrm{N}=61)$ with family members $(\%)$ in rural areas

Currently, as seen from Table 1, Mari is more spoken by parents among themselves (51\%), than with children $(43,6 \%)$ and almost twice as little mixed language is used among parents than with children (17,6\% vs 38,2\%), which indicates clearly weakening of native Mari language position.

To my surprise, the statistical analysis showed that almost twice as many adults spoke exclusively in Russian to each other than with their children (31.4\% and $18.2 \%$, respectively). Such figures could be interpreted as a clear indicator of Mari parents' concerns regarding in what language to speak with their children, and an attempt to control it consciously. However, this conclusion should be made with a caution as, indeed, the questionnaire data does not reflect the details of language choice made by parents (in which domestic situations they speak Mari, what level of Mari, etc.)

In comparison to adults, the linguistic behavior of children varied to a lesser degree, though demonstrated the same tendency regarding the use of languages (Table 2). However, by comparing two tables, one can see some difference in the linguistic preferences of two generations. While Mari parents tended to prefer using their native language when communicating 


\begin{tabular}{|lr|r|r|}
\cline { 2 - 5 } \multicolumn{1}{l|}{} & \multicolumn{2}{l}{ Children } & \multicolumn{2}{l|}{ Russian } \\
\hline Family member & \multicolumn{1}{l|}{ Mari } & Mari and Russian & 5.6 \\
\hline Grandparents & 65.9 & 52.3 & 9.0 \\
\hline Parents & 38.7 & 60.0 & 14.1 \\
\hline Siblings & 25.9 & & \\
\hline
\end{tabular}

Table 2: Language use of children $(\mathrm{N}=\mathbf{2 2 2})$ with family members (\%) in rural areas

with their children, the children preferred to switch codes. Similar proportions of both generations used the Mari language with one another (43.6\% and $38.7 \%$ ) but differed regarding the use of Russian (18.2\% and 9\%). Such a discordance in the evaluation of the degree to which each language is used, can be caused by a different language position between two generations. Which language do parents address their children in? In what language(s) do children reply? Why? As seen from previous numerous studies (CurdtChristiansen 2013; Folge 2013; Kopeliovich 2013, etc.), the language behavior of participants depends on various conditions (e.g. the interrelations of family members, the level of language knowledge of the participants, attitudes to the languages, the language strategies of parents). However, in order to answer these questions regarding Maris, it is necessary to conduct long-term research within Mari families with account of foregoing theoretical and practical conclusions.

Questioning showed that the rate of the Mari and Russian language usage by family members (grandparents, parents, children, and siblings) in rural area varies according to the generation, involved (Table 2). That confirmed the generally known fact that nowadays, the Mari language is mostly used with grandparents, and least with siblings. Generally, the proportion of the Mari language usage by the younger generation with family members (grandparents, parents, and siblings) was roughly equal to 3:2:1, an indicator of the weakening of intergenerational language transmission among Maris.

Thus, despite the widespread opinion that rural areas are a locus for the maintenance of minority languages and culture (Lallukka 1990; Ivanov 2004; Sanukov 2011), the process of ethnic erosion, is clearly evident there. Regarding Mari, as well as other minority languages in Russia, it manifests itself in gradual linguistic assimilation, further followed by ethnic assimilation of people. Taking into account the fact that the process of language 
loss is a global disaster, it may be assumed that the Mari language will fit into those half of the world languages that would have disappeared by 2100, as reported by UNESCO (Laccino 2015)

\section{Factors affecting the languages used within Mari families}

Several factors affected language usage, justified by participants as their motives for choosing a "permanent language" of communication within their family. The linguistic behavior of family members in any given situation was not the point of this paper; the focus was on the survey question "What language do you speak with your family members?" in an attempt to answer the implicit question "Why did you choose this/or that language(s) for communication in your family?". For this purpose, all the collected responses were generalized and, in combination with some previous conclusions, are provided below.

One of the main factors highlighted by the survey respondents is that of community. There are a variety of research papers describing the mechanisms and effect of community on the linguistic behavior of children growing up in immigrant families (Romaine 1995; Curdt-Christensen 2013; Kopeliovich 2013). Such families have one common feature: despite various levels of knowledge of parental or community languages, children more or less practice the use of their native minority language(s) among their families. This means that parents somehow linguistically resist the effect of the majority community. However, the situation is different in the case of the Maris: an investigation into the motives for language choice in the family domain reveals that the majority of rural Russian- and Marispeaking families justify their specific linguistic behavior by referring to the effect the community they live in has upon them. Two examples best illustrate this linguistic position among the Maris:

1) Ялыште чыланат марий улыт, марла кутырат. Меат ешыите марла кутырена. Ала-кузе, мо, сайын огеш чуч, рушла кутыраш тӱналына гын... марла веле (Анастасия, 36 ий; еш № 2).

Everybody speaks Mari in our village. We also speak Mari in our family. Somehow, hm, it seems uncomfortable if we start speaking Russian... Only Mari (Anastasia, 36; Family 2). 
2) В семье говорим по-русски. Да у нас вся деревня считается русской. Соседи все русские. Поэтому неудивительно, что в семье тоже говорим по-русски (Ольга, 27 лет; семья № 8).

We all speak Russian in our family. Our village is considered Russian. All neighbors are Russian. That is why it is not surprising that everyone speaks Russian in our family (Olga, 27; Family 8).

The research shows that all of these families are similar, as they demonstrate an absence of language management in the family (because "everybody speaks ... language") and the surrounding community has a strong effect on which language is spoken. In the latter case, the family has converted to the community language policy, which in this context is often Russian. In addition, it is the lack of a language policy within the family that partly justifies the existence of the next motive, the habitual way of communication between spouses:

3) Я понимаю марийский и могуговорить на нём. Но для меня привычнее говорить по-русски. Я всегда разговариваю по-русски (Ольга, 27 лет; семья № 8).

I understand Mari and can speak it. But it is more habitual for me to speak Russian. I always speak Russian (Olga, 27; Family 8).

This motive is related to the following one, the language used from the beginning of communication between the spouses. Such couples are more active in language management regarding their children:

4) Влад дене рушла кутырена... Ме тӱналтыш гычак рушла кутырена. Марла тудо мошта... Но шуэн мый денем кутыра. Южгунам мый тудлан иктаж-мом марла ойлем, мутым, але мыскарам ыштем, но тудо рушла вашешта (Лариса, 33 ий, еш № 6).

I speak Russian with Vlad... We have been speaking the Russian language since we met. He knows Mari... But he rarely speaks Mari with me. Sometimes I say something to him in Mari, some expressions, make jokes, but he always replies to me in Russian (Larisa, 34; Family 6).

Thus, one can conclude that neither the level of knowledge of Mari nor any other ideological stances are influencing people's linguistic behavior.

Among the other motives for language choice within the family domain, one should address the following category, strong ethnic values (applied to Group 1). These values are: 


\section{Elena Vedernikova}

1. Sense of ethnicity, or association of native Mari language with ethnic affiliation:

5) Ме марий улына да марла кутырена... Марий ешыште шочынна... Омак умыло, молан марий-влак шке йочашт дене рушла кутырат? Меже вет марий улына. Тидыже мемнан йылме... (Анна, 26 ий; еш № 3).

We are Mari and we speak Mari... We were born in Mari families... I really do not understand why Mari people speak Russian with their children. We are Mari. This is our language... (Anna, 26; Family 3).

2. Homeland, or association of one's native language with the region one lives in (an indication of regional identity):

6) Марла веле кутырена... Марий Эльште вет илена... Тиде мемнан йылме (Мария, 37 ий; еш № 1).

We only speak Mari... We live in Mari El... And this is our language (Maria, 37; Family 1).

A pragmatic approach to the language issue (one prioritizing learning, teaching, and speaking) has a negative effect in relation to Maris speaking their native language (Vedernikova 2014a). This was more applicable to Group 3, which includes the people who were first to abandon their ethnic language and, in general, identity:

7) $\mathrm{Mbl} \mathrm{с} \mathrm{детьми,} \mathrm{в} \mathrm{семье} \mathrm{не} \mathrm{говорим} \mathrm{по-марийски.} \mathrm{По-русски}$ разговариваем... Почему? А зачем он нужен? Русский больше нужен... Марийский - это уже прошлое. На нём только в деревнях с бабушками разговаривать и всё (Валентина, 37 лет; семья № 7).

We do not speak Mari with our children. We speak Russian... Why? And why is it necessary? Russian is more necessary... The Mari language is already the past. It is only for speaking with grannies in villages and that is all (Valentina, 37; Family 7).

As one can conclude from this passage, the value attached to the Russian language by Maris is associated with the present and the future, while, in contrast, Mari is considered a relic. Such utterances are rather typical of linguistically (and also ethnically) assimilated Maris, those who are categorized as "ethnic nihilists" by Sanukov (2011) and Soloviev (2012). To my mind, this is a substantial reason for the endangerment of the Maris as a people. 
If one uses the categorization of Romaine (1995), the next motive can be identified as an intuitive division between one's home language and the language of the community, which was applicable to Groups 1 and 2, as the interviewees could not give a clear explanation for such kinds of linguistic behavior in different situations, an idea best exemplified by the following interview passage:

8) С мужем и детьми говорим по-русски... Мь все знаем марийский язык, но говорим только по-русски. По-марийски говорим с соседями и знакомыми... в наших родительских семьях мы тоже говорим порусски или по-марийски очень мало. Так принято, что ли... Не знаю, как объяснить (Валентина, 37 лет; семья № 7).

We speak in Russian with my husband and children... We all know the Mari language, but we speak only Russian. We speak Mari with our neighbors, some familiar people... in our parental families, we also speak Russian, or speak very little Mari. It is a habit... I do not know how to explain it (Valentina, 37; Family 7).

A short content analysis has revealed that the selection of either Mari or Russian as a language of communication in a family is the result of various factors that can be categorized as cultural, social, and psychological. Thus, selection of Mari appears to be explained by ethnic values, while the use of the Russian language was justified by evoking e.g. "profit" or "convenience". This once again indicates that the languages have different social roles within Mari society (Ivanov 2004; Kuznetsova 2004), which is one of the most substantial reasons for the strengthening of the position of the Russian language over Mari in the Russian post-Soviet space.

\section{Code-switching within families}

Among the variety of reasons for code-switching indicated by the interviewees, linguistic factors were most significant. They included:

1. A lack of a Mari vocabulary caused by the absence of terminology in some fields (e.g. politics, public life, scientific activities, and engineering), which is a topical issue with regard to the modern use of the Mari language (Ivanov 2004; Sibatrova 2012). 
9) Южгунам ме руш мутым кучылтына але рушла кутырена. Мый ом пале южо мутшым марла. Ну, теве ом пале, кузе марла «компьютер», «телефон» манаш. Рушла веле палем. Ну вот, рушла и ойлем (Анастасия, 36 ий; еш № 2).

Sometimes we use some Russian words or speak Russian. I do not know some words in Mari. For instance, I do not know the word "computer" or "telephone"13 in Mari. I know [them] only in Russian. So, I say [them] in Russian (Anastasia, 36; Family 2).

2. A limited command of Mari, often caused by either an absence of language management within a family, or by an indifferent attitude of the community to this issue, which appeared to have a strong effect on people's linguistic preferences. Such a tendency generally has its roots in the 1960s, when the policy of Russification was followed by elimination of Mari as a language of instruction in schools, and further negative re-evaluation of the role of native minority languages and cultures (Sanukov 1992). This resulted "in a generation of Maris growing up with a command of their language as vernacular" (Ivanov 2004: 52) and striving for diverge from their ethnic roots. That Soviet policies have had a long-term effects, which have manifested in passing this tendency of indifference to successive generations.

3. Dialectal differences that cause misunderstandings and awkward situations during communication among two or more speakers belonging to various subdialects, as exemplified by the following utterance:

10) Наш папа говорит и на русском и на марийском одновременно... Часто мешает языки. Вообще, он не говорит много по-марийски с нами. Он из Мари-Турекского района. Они говорят 'Шӱрым волтен пу' вместо 'Шӱрым пыштен пу'... Однажды он попросил меня: 'Мыламат ширьм волтен пу'. Ну, я взяла и поставила кастрюлю на пол. Он был в шоке. [смеется] C тех пор он говорит: 'Ты говоришь на своём языке, я на своём'. Я прошу его: 'Пожалуйста, хоть в деревнето говори по-марийски, ведь все же марийць здесь' [пауза] Однажды была ситуация тетом на сенокосе. Там много народу... И тут он спросил: 'Кӧ вӥчамбакыже кӥза?' Все мои родственники упали: 'Какой «вӥчамбал»? [пауза] А мо, манеш?' (Людмила, 34 ий; еш № 5)

Our father speaks in Russian and in Mari... He often mixes [i.e. switches from Mari to Russian and vice versa] languages. Well, he doesn't speak Mari too much with us. He is from the Mari-Turek district. They say 'šürym volten pu' [lit. 'drop some soup'] instead of 'šürym pyšten pu' ['put down some soup']... Once he asked me, 'Mylamat šürym volten pu' [lit. 'drop me some soup']. I took the saucepan and put it on the floor. He was shocked. [laughing] And since then he says, 'You and I speak different languages'. I 
asked him, 'Please, speak in Mari at least in the village, because everybody is Mari'. [pause] Once, during haymaking, there was a situation. There were a lot of people, and he asked 'Kö vüčambakyže küza?' [Who will go to the hayloft?]. All my relatives burst out laughing, 'What's vüčambal?' [pause] 'But how?', he asked (Liudmila, 34; Family 5).

As one can see from this case, the switch to another language occurred not because of any mutual intelligibility, but for a psychological reason (fear of being the subject of some emotional reaction from the community).

4. Weak ethnic self-awareness, which has its roots in a variety of reasons. For one, it is a consequence of the Soviet policy of assimilation, which accelerated the process of assimilation during the second half of the twentieth century. Modern processes in Russian society (strengthening the position of Russian in all domains at the expense of minority languages) also exert a negative impact on the ethnic self-identification of many minority peoples. As language and ethnicity are closely interrelated for most minority groups in Russia, a decrease in the position of one's native language is followed by an increased tendency to diverge from one's own ethnic group.

\section{Conclusions}

Comparative analysis of the survey data has shown that the linguistic behavior of children and adults varies. Members of the younger generation tends to mix languages with their parents, while older people (parents, grandparents) are more likely to speak Mari, which indicates their conscious approach to the language issue within the family. A comparison of the language choice of two generations revealed a clear weakening of intergenerational language transmission, which is an indicator of ethnic erosion among the Maris.

The qualitative analysis of the interview data showed that the language of the community was the strongest determining factor of language choice among rural Mari families.

Another group of factors affecting linguistic behavior within the family can be characterized as psychological, as they reflect people's subjective position with regard to language. Thus, for Group 1 (Mari-speaking families), it was the association of one's native language with one's homeland and ethnicity, which can indicate some level of ethnic self-awareness among rural Maris. In turn, cases of ethnic indifference, i.e. usage of the 
dominant non-native language as a habitual way of communication, were observed among the families who spoke mainly in Russian (Group 3). The relatively small Mari lexicon and dialectal distinctions were the next substantial factors for the mixing of languages. As argued by researchers (Ivanov 2004; Sanukov 2011), a limited command of one's native language, and, separately, low ethnic self-awareness, are also reasons for partial or complete switching to Russian by the Maris.

The investigation into the motives for language choice among rural families showed that in most cases it is determined by language ideology, which is in line with the argument of Spolsky (2004) regarding the determinants of language policy. However, one cannot omit the other various factors, which are intertwined with one another and require further, more detailed investigation.

Elena Vedernikova Department of English Applied Linguistics School of English and American Studies Eötvös Loránd University Budapest, Rákóczi út 5. H-1088 


\section{Notes}

1 There are two literary standards, Meadow and Hill Mari

2 Although Ehala \& Vedernikova (2015) reported unlimited radio broadcasting time in the Mari language, the situation has changed, with a reduction in radio broadcasting in Mari.

3 Some subgroups of Maris were either forcefully annexed to Russian principalities much earlier (in the 9th-12th centuries) and underwent full ethnic assimilation, or voluntarily joined the Russian state, as was the case with the Hill Mari subgroup during the 16th century (Bakhtin 2012)

4 As argued by Sanukov (2011), the results of the 2002 Census can be disregarded due to the different methodological approach to questions about native language use.

5 Geographical coordinates $56^{\circ} 44^{\prime} \mathrm{O} 8.8^{\prime \prime} \mathrm{N} 48^{\circ} 35^{\prime} 54.5^{\prime \prime} \mathrm{E}$

6 Geographical coordinates $56^{\circ} 45^{\prime} 55.9^{\prime \prime} \mathrm{N} 48^{\circ} 40^{\prime} 12.4^{\prime \prime} \mathrm{E}$

7 Geographical coordinates $56^{\circ} 48^{\prime} \mathrm{O} 2.9^{\prime \prime} \mathrm{N} 48^{\circ} \mathrm{OO}$ 'O5.3"

8 Geographical coordinates $56^{\circ} 42^{\prime} 17.4^{\prime \prime} \mathrm{N} 48^{\circ} 31^{\prime} \mathrm{O} 4.2^{\prime \prime} \mathrm{E}$

9 Geographical coordinates $56^{\circ} 32^{\prime} 35.2^{\prime \prime} \mathrm{N} 48^{\circ} 24^{\prime} \mathrm{O} 7.3^{\prime \prime} \mathrm{E}$

10 Geographical coordinates $56^{\circ} 52^{\prime} 16.9$ " $\mathrm{N} 48^{\circ} 55^{\prime} 39.2^{\prime \prime} \mathrm{E}$

11 The interviewee was Olga (27), the youngest daughter of Igor and Svetlana.

12 Geographical coordinates $57^{\circ} 07^{\prime} 27.1^{\prime \prime} \mathrm{N} 48^{\circ} 19^{\prime} 20.8^{\prime \prime} \mathrm{E}$

13 In this case, by saying "Russian words" the respondent, indeed, indicates loanwords. This is due to the lack of understanding that Russian does not exist in vacuum either. In the meantime, much of what is considered "Russian" is simply internationalisms. So, here one could speak about the usage of internationalisms in Mari speech.

\section{References}

BAкнтіN 2012 = Бахтин, А. Г.: Марийский край в ХIII-XVIII веках: очекри истории. Монография. Йошкар-Ола. МарГУ.

Bourhis, Richard, Giles Yvon \& Howard and Doreen Rosenthal 1981: Notes on the construction of a 'Subjective Vitality Questionnaire' for ethnolinguistic groups. - Journal of Multilingual and Multicultural Development 2. 144-155.

Bychenko, Yuriy \& Viktor Shabanov 2012 = Быченко, Ю. и Шабанов, В.: Современная миграция сельского населения: особенности, направления, последствия. - Вестник Саратовского Государственного Социально-экономического унивеpumema 2. 136-142. <https://cyberleninka.ru/article/n/sovremennaya-migratsiyaselskogo-naseleniya-osobennosti-napravleniya-posledstviya > 17 January 2016

Bychenko, Yuriy \& Viktor Shabanov 2014 = Быченко, Ю. и Шабанов, В.: Влияние миграции на демографическое и этноструктурное развитие российского села. - Мир России 1. 167-187. <https://cyberleninka.ru/article/v/vliyaniemigratsii-na-demograficheskoe-i-etnostrukturnoe-razvitie-rossiyskogo-sela> 3 March 2016

Chuкsin 2008 = Чуксин, Н.: Марий Эл. Часть первая. - Заметки из одного путешествия. <http://samlib.ru/c/chuksin_n_j/mari_el_1.shtml> 12 December 2015 


\section{Elena Vedernikova}

Curdt-Christiansen, XiaO 2013: Negotiating family language policy: doing homework.

- Mila Schwarts \& Anna Verschik (eds), Successful Family Language Policy: Parents, Children and Educators in Interaction. New York, London. Springer. 277-295.

Bell, Allan 2014: The Guidebook to Sociolinguistics. Chichester: Wiley Balckwell.

Derevnya 2014a = Деревня Дементьево (Русские Кузнецы, Кугорнымбал). - Марий Эл. <http://www.12rus.ru/List/25/1116/> 15 February 2016

DerevnYa 2014b = Деревня Шура. - Марий Эл. <http://www.12rus.ru/List/29/1861/> 15 February 2016

Fishman, Joshua, Robert Cooper \& Andrew Conrad 1971: The spread of English: the sociology of English as an additional language. Rowley, MA. Newbury House.

Folge, Wright 2013: Parenthal ethnotheories and family language policy in transnational adoptive families. - Language Policy 12(1). 83-102.

Hint, Matti 1995: Bilingualism as a Social and Political Problem with a Reference to Estonia and its Neighbors. - Studi Finno-Ugrici 1. Annali dell Instituto universitario Orientale di Napoli. 15-28.

Ivanov, Ivan 2004 = Иванов, И. Г.: Языковая ситуация в Республике Марий Эл. János Pusztay (ed), Specimina Sibirica. Savariae. 50-59.

Knorre, Boris \& Elena Konstantinova 2013 = Кнорре, Б. \& Константинова, Е.: Марийская народная вера и борьба мари за наииональные интересы в последнее десятилетие <http://www.keston.org.uk/_russianreview/edition42/o3-marifrom-knorre.html> 2 December 2015

KondRASHKINA 2014 = Кондрашкина, Е. А.: Финно-угорские языки России в контексте языкового строительства. - Языковая политика и языковые конбликты в современном мире. Москва. 183-188. <http://www.philology.ru/linguistics2/ kondrashkina-14.htm> 8 February 2016

Kopeliovich, Shulamit 2013: Happylingual: a family project for enhancing and balancing multilingual development. - Mila Schwarts \& Anna Verschik (eds), Successful Family Language Policy: Parents, Children and Educators in Interaction. Springer: New York, London. 249-275.

KuZNETSOva 2004 = Кузнецова, М. Н.: О психологическом факторе билингвизма (на примере марийского языка). - János Pusztay (ed.), Specimina Sibirica. Savariae. $60-70$.

LACCINA, LudoviCA 2015: Unesco: half of the world languages will disappear by 2100. - International Business Times. April 24. <http://www.ibtimes.co.uk/unesco-halfworlds- languages-will-disappear-by-2100-1498154>13 January 2016

LallukKa, Seppo 1990: The East Finnic Minorities in the Soviet Union. An Appraisal of the Erosive Trends. Helsinki: Suomalainen Tiedeakatemia.

Lallukкa, Seppo 1997 = Лаллукка, С.: Восточно-финские народы России. СанктПетербург: Европейский Дом

NATSIONALNYI SOSTAV 2012 = Национальный состав республики Марий Эл. Итоги Всероссийской переписи населения 2010 года. Статистический сборник. Йошкар-Ола. <http://maristat.gks.ru/wps/wcm/connect/rosstat_ts/maristat/ resources/f2ff83804132azef93b7f7 367ccdof13/\%Do\%BD\%Do\%Bo\%D1\%86\%Do\%B8 \%Do\%BE\%Do\%BD\%Do\%Bo\%Do\%BB\%D1\%8C\%Do\%BD\%Do\%BE\%D1\%81\%D1\% $82 \% \mathrm{D} 1 \% 8 \mathrm{C} \% \mathrm{Do} \% \mathrm{~A} 2 \% \mathrm{Do} \% 9 \mathrm{E} \% \mathrm{Do} \% 9 \mathrm{C}+4 . \mathrm{pdf}>2$ February 2016 
PoseloK 2014 = Поселок Солнечный. - Марий Эл. <http://www.12rus.ru/List/33/2709/> 24 February 2016

Nurmuкhametova, Salima 2016 = Нурмухаметова, Салима: Миграция сельских жителей. - Novainfo.Ru. 58. 1. 554-557/

Romaine, Suzanne 1995: Bilingualism. 2nd edition. Oxford: Blackwell Publishing.

SANuкоv 1992 = Сануков, К. Н.: Марийцы: прошлое, настоящее, будущее. <www. suri.ee/r/mari/sanukov.html> 28 January 2016

SANUKOV 1996 = Сануков, К. Н.: Историческая судьба марийского народа и задачи марийского национального движения. Пробуждение финно-угорского Севера. Oпьы Марий Эл. Том 1. Москва. ОУП Института этнологии и антропологии PAH. 41-63.

SANuкоV 2011 = Сануков, К. Н.: Финно-угосркие народы России: прошлое и настоящее: монограбия. Йошкар-Ола. Мар.гос.ун-т.

SBORNIK 2005 = Сборник материалов об этнической ситуации в республике Марий Эл и социально-культурном положении народа. Йшкар-Ола. Марийское Книжное издательство.

SHAMiev 2010 = Шамиев, В.: Чыным шыташ ом шоно. Марий Ущем - марий куат. Йошкар-Ола. 113-122.

Shvetsova, Galina 2008 = Швецова, Г.: Образовательная политика в условиях модернизации образовательной системы. Йошкар-Ола: Мар. гос. ун-т.

Shvetsova, Galina 2012 = Швецова, Г.: Состояние и перспективы развития марийского языка. - Пашана ятьц, корнына кужу. Йошкар-Ола. 56-66.

Spolsky, Bernard 2004: Language Policy. Cambridge University Press.

Soloviov 2012 = Соловьёв, В.: Размышления о будущем марийского. - Пашана ятыр, корнына кужу. Йошкар-Ола. 3-10.

VASIUTINA 2009 = Васютина, Л.: Деятельность национальной библиотеки им С.Г.Чавайна по сохранению национально-культурного наследия Республики Марий Эл. - Материалы общероссийской научно-практической конференции «Роль и место национальных библиотек в этнокультурном пространстве региона (2 2о-летию присвоения Республиканской библиотеке Удмуртской АССР статуса «нациоанльная»). Ижевск. 27-37. <http://unatlib.org.ru/download/ Publications/Konf_status/mater_konf.pdf $>19$ December 2015

Vedernikova, Elena 2014a: Activism of the Mari younger generation in the maintenance of the Mari language. - Johanna Laakso (ed.), Dangers and Developments: On Language Diversity in a Changing World. Studies in European language Diversity 34. 46-56. Mainz.

Vedernikova, Elena 2014b: Impact of native culture and religion on the Mari language. - Eesti ja soome-ugri keeleteaduse ajakiri / Journal of Estonian and FinnoUgric Linguuistics 5(2). 185-203. 


\section{Appendix. Questionnaire.}

1. In what language do you speak with your wife/husband? Why?

2. In what language do you speak with your children? Why?

3. Are there cases where you address your children in different languages?

- If yes, why do you speak different languages?

4. Are you consistent in speaking Mari/Russian with your children? Why?

5. Do you teach your children Mari/Russian?

- If yes, in which way do you do that?

6. What is the main reason for speaking Russian/Mari in your family?

7. What are the attitudes of your family members to Mari and Russian? 